\title{
Preparation and Electrochemical Performance of CNT Electrode with Deposited Titanium Dioxide for Electrochemical Capacitor
}

\author{
Hong-II Kim, Han-Joo Kim, ${ }^{\dagger}$ Masayuki Morita, ${ }^{\dagger}$ and Soo-Gil Park* \\ Department of Industrial Engineering Chemistry, Chungbuk National University, Cheong-ju 361-763, Korea \\ ${ }^{*}$ E-mail: sgpark@cbnu.ac.kr \\ ${ }^{\dagger}$ Pureechem Co., Ltd., Cheong-ju 361-763, Korea \\ ${ }^{\star}$ Department of Applied Chemistry, Graduate School of Science and Engineering, Yamaguchi-University, \\ 2-16-1 Tokiwadai, Ube 755-8611, Japan \\ Received April 15, 2009, Accepted January 9, 2010
}

\begin{abstract}
To reduce polarization of electrochemical capacitor based on carbon nanotube, titanium oxide nanoparticles were deposited by ultrasound. The pore distribution of $\mathrm{TiO}_{2} / \mathrm{CNT}$ nanoparticle exhibited surface area of $341 \mathrm{~m}^{2} \mathrm{~g}^{-1}$ when $\mathrm{TiO}_{2}$ content was $4 \mathrm{wt} \%$, which was better than that of pristine CNT with surface area of $188 \mathrm{~m}^{2} \mathrm{~g}^{-1}$. The analyses indicated that titanium oxide (particle diameter $<20 \mathrm{~nm}$ ) was deposited on the CNT surface. The electrochemical performance was evaluated by using cyclic voltammetry (CV), impedance measurement, and constant-current charge/discharge cycling techniques. The $\mathrm{TiO}_{2} / \mathrm{CNT}$ composite electrode showed relatively better electrochemical behaviors than CNT electrode by increasing the specific capacitance from $22 \mathrm{Fg}^{-1}$ to $37 \mathrm{Fg}^{-1}$ in $1 \mathrm{M} \mathrm{H}_{2} \mathrm{SO}_{4}$ solution. A symmetric cell assembled with the composite electrodes showed the specific capacitance value of $11 \mathrm{Fg}^{-1}$ at a current loading of $0.5 \mathrm{mAcm}^{-2}$ during initial cycling.
\end{abstract}

Key Words: Electrochemical capacitor, Titanium dioxide, CNT, Polarization

\section{Introduction}

Electrochemical capacitor is an electrochemical energy storage device utilizing the electric charges accumulated at the interface between the electrode and the electrolyte to form the electric double layer. ${ }^{1-5}$ It has been increasingly getting attention not only for the established applications as backup power to electronic equipments and mobile devices, ${ }^{6,7}$ but also for high power applications in pulsed lasers and electric vehicles.

Advancement in energy-storage technologies can benefit from the shift from conventional to nanostructured electrodes. For electrochemical capacitors, focus has been on nanostructured carbons, nanotubes, and nanotemplates. ${ }^{10,11}$ Among these materials, carbon nanotubes (CNTs) have been considered ideal for electrochemical capacitors, owing to the advantages such as accessible surface area, excellent electronic conductivity, and good stability. ${ }^{12-17}$

On the other hand, CNT grows the polarization when CNT electrode reacts with electrolyte through the electrode/electrolyte interface. Generally, polarization is the change of potential of an electrode from its equilibrium potential upon the application of a current. The phenomenon of transportation of electrical charge from one part of the electrochemical cell to another, occurring mainly as electromigration of ions, but it can also occur by diffusion of ions. ${ }^{5,17}$ The specific capacitance of the electrochemical capacitor based on CNTs has been reported to present lower capacitance of about $20 \sim 30 \mathrm{Fg}^{-1}$. The lower capacitance is partially attributed to poor wettability of electrode material, which leads to a lower usable specific surface area for charge storage. ${ }^{18}$ As another reason, polarization may reduce charge accumulation of the ions on the double-layer. For these reasons, reducing the polarization of activated carbon by intro- ducing $\mathrm{TiO}_{2}$ nanoparticles has been considered to be an effective approach to improve the capacitance of the double-layer capacitors. ${ }^{5}$ In this study, we considered that wettability and polarization of the nanocomposite electrode depend on the content of $\mathrm{TiO}_{2}$ deposited on CNT.

\section{Experimental}

The $\mathrm{TiO}_{2} / \mathrm{CNT}$ nanocomposite material was prepared by solgel process with ultrasound in 2-propanol. The starting material, titanium isopropoxide (Aldrich Co., Ltd.) was commercially available with purity of $99 \%$. The average outer diameter of CNT (MWNT type, Iljinnanotech. Co., Ltd.) was 15 20 nm and the length was $10 \sim 20 \mu \mathrm{m}$. The CNT was chemically oxidized in $1 \mathrm{M} \mathrm{H}_{2} \mathrm{SO}_{4}$ for $48 \mathrm{~h}$ at $80^{\circ} \mathrm{C}$ and dried at $120^{\circ} \mathrm{C}$ overnight. Titanium isopropoxide $(0.2,0.4,0.6$ and $0.8 \mathrm{M})$ and $1 \mathrm{~g} \mathrm{CNTs}$ were mixed in 2-propanol $(200 \mathrm{~mL})$ with ultrasound, respectively. Then they were mixed with stirring under ultrasound for $30 \mathrm{~min}$. The mixture was separated from the solvent by drying at $90{ }^{\circ} \mathrm{C}$ into vacuum oven overnight. The resultant was calcinated at 450 ${ }^{\circ} \mathrm{C}$ for $2 \mathrm{~h}$ in air at a heating rate of $5^{\circ} \mathrm{C} / \mathrm{min}$ to form $\mathrm{TiO}_{2} / \mathrm{CNT}$ nanocomposite. The samples were characterized by X-ray diffraction (XRD, SCINTAG DMS2000) and transmission electron microscope (TEM, model Joel-1020 Carl Zeiss TEM109) was used to monitor the particle size at each synthesis step. X-ray Photoelectron Spectroscopy (XPS, ESCALAB 210) was used to obtain the structure of nanocomposite.

The working electrode was prepared from a mixture paste of $\mathrm{TiO}_{2} / \mathrm{CNT}$ nanocomposite powder, ketijen black $(\mathrm{KB})$ as an electronic conductor additive, and polyvinylidene fluoride (PV$\mathrm{dF}$ ) binder mixed with the weight ratio of 85:10:5 in N-Methyl2-Pyrrolidone (NMP). The electrode was dried under vacuum 
at $120{ }^{\circ} \mathrm{C}$ for $24 \mathrm{~h}$ before electrochemical evaluation. Electrochemical measurements were conducted using conventional three-electrode configuration and symmetrical full cell. The $\mathrm{TiO}_{2} / \mathrm{CNT}$ composite on carbon paper electrode was used as the working electrode. A Pt wire and $\mathrm{KCl}$-saturated $\mathrm{Ag} / \mathrm{AgCl}$ were used as the counter and reference electrodes, respectively. The $1 \mathrm{M} \mathrm{H}_{2} \mathrm{SO}_{4}$ aqueous solution was used as the electrolyte. Cyclic voltammetry (CV) was measured on range of $0 \sim 800$ $\mathrm{mV}$. Scan rate was $50 \mathrm{mVs}^{-1}$ and it was shown after 3 th cycle. And cycling performance of the two electrodes in cell was measured at $0.5 \mathrm{mAcm}^{-2}$ between 0 and $1000 \mathrm{mV}$. All the measurements were taken at room temperature and under nitrogen atmosphere.

\section{Results and Discussion}

In order to show actual size and formation of deposited $\mathrm{TiO}_{2}$ particle, Fig. 1 (b) (e) present TEM images of $\mathrm{TiO}_{2} / \mathrm{CNT}$ composite materials with different $\mathrm{TiO}_{2}$ weight ratio. Some of the shapes of these samples were classified as a part of a straight form with a thick outer diameter and another rest as a curved style with a narrow outer diameter. The $\mathrm{TiO}_{2} / \mathrm{CNT}$ composite materials were different from the result in Fig. 1. From above results, our attempt to prepare the $\mathrm{TiO}_{2} / \mathrm{CNT}$ composite materials was successful. And the more the $\mathrm{TiO}_{2}$ was inserted, the more the deposited $\mathrm{TiO}_{2}$ grains clumped together. The particles are spherical with the size of about $10 \sim 20 \mathrm{~nm}$ in diameter.

Fig. 2 shows the X-ray diffraction (XRD) patterns of the $\mathrm{CNT}$ and the CNT on which $\mathrm{TiO}_{2}$ was deposited with contents of $4,6,17$, and $32 \mathrm{wt} \%$. After the stoichiometric precursor of $\mathrm{TiO}_{2} /$ CNT composite has been calcinated at $450{ }^{\circ} \mathrm{C}$ for $2 \mathrm{~h}$ in air, the anatase phase of $\mathrm{TiO}_{2}$ has been appeared. The peaks located at $25.66^{\circ}$ and $42.50^{\circ}$ could be identified to the reflection from the (002) and (100) planes of CNT and the additional peaks observed at $25.07^{\circ}, 37.66^{\circ}, 47.74^{\circ}, 53.8^{\circ}, 54.29^{\circ}$ and $62.44^{\circ}$ are corresponding to (101), (004), (200), (105), (211) and (204) planes of anatase $\mathrm{TiO}_{2}$ (JCPDS no. 21-1272). ${ }^{19}$ All of broaden and weaken peaks in Fig. 2 imply that $\mathrm{TiO}_{2} / \mathrm{CNT}$ composite materials consisted of $\mathrm{TiO}_{2}$ and CNT nanoparticles belong to low-dimensional states. The CNT (002) reflection overlaps the anatase $\mathrm{TiO}_{2}$ (101) reflection. As is seen in Fig. 2, the $\mathrm{TiO}_{2} / \mathrm{CNT}$ composite shows CNT peak, and also anatase peaks of the composites grow as the $\mathrm{TiO}_{2}$ content increases. And no peak of other phases was observed, which indicates that the composite materials are well crystallized.

The X-ray photoelectron spectroscopy (XPS) which was performed to investigate the chemical bonding state of $\mathrm{Ti}$ in the $\mathrm{TiO}_{2} / \mathrm{CNT}$ composite material prepared at $450{ }^{\circ} \mathrm{C}$ for $2 \mathrm{~h}$ is shown in Fig. 3. The Ti $2 p$ signal of the $\mathrm{TiO}_{2} / \mathrm{CNT}$ composites shows a Ti $2 \mathrm{p}_{1 / 2}$ peak centered at $464.8 \mathrm{eV}$ and a Ti $2 \mathrm{p}_{3 / 2}$ peak at $459 \mathrm{eV}$. The observed binding energies (B.E.) of Ti $2 \mathrm{p}_{1 / 2}$ and Ti $2 \mathrm{p}_{3 / 2}$ peaks for $\mathrm{TiO}_{2} / \mathrm{CNT}$ composites are near to those observed for $\mathrm{TiO}_{2}$ (458.5 and $464.2 \mathrm{eV}$, respectively). The atomic $\%$ of $\mathrm{TiO}_{2}$ nanoparticle $\left(C_{\mathrm{x}}\right)$ was calculated peak area from the equation (1):

$$
C_{\mathrm{x}} \text { atomic } \%=\left[\left(I_{i} / F_{i}\right) / \Sigma(I / F)\right] \times 100
$$
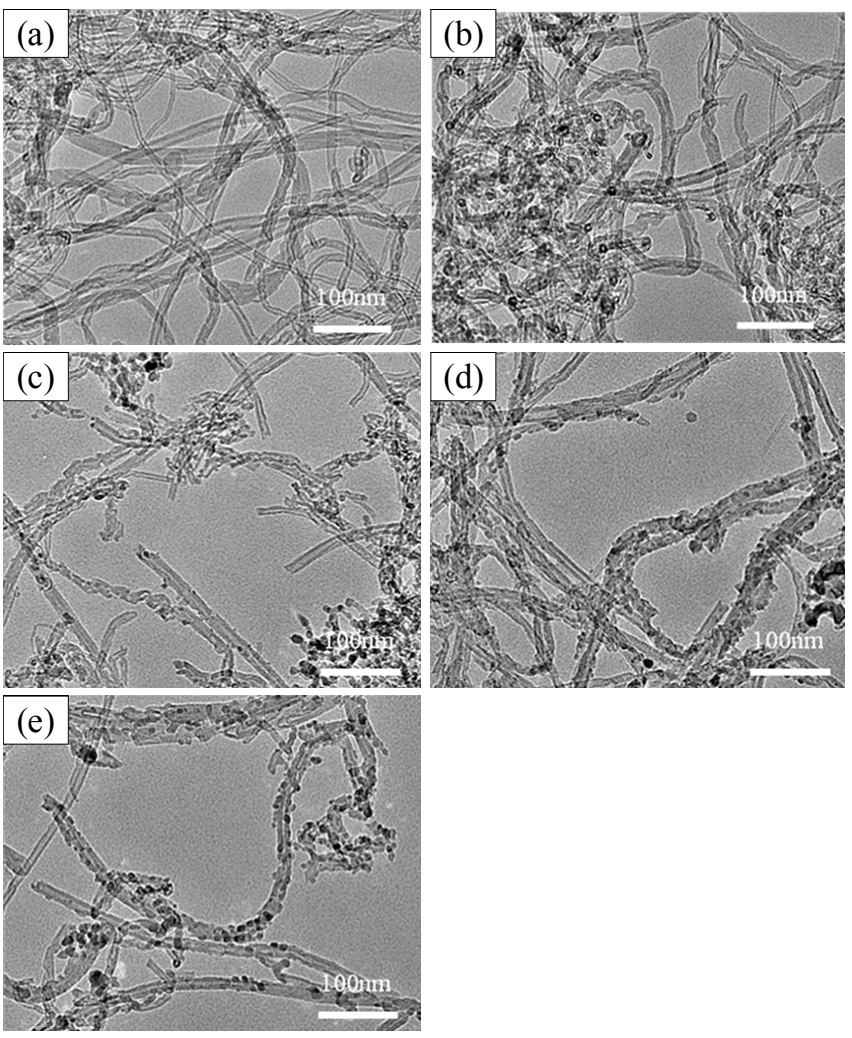

Figure 1. TEM images of (a) the pristine $\mathrm{CNT}$ and $\mathrm{TiO}_{2} / \mathrm{CNT}$ nanocomposites with deposited $\mathrm{TiO}_{2}$ contents of (b) $4 \mathrm{wt} \%$, (c) $6 \mathrm{wt} \%$, (d) $17 \mathrm{wt} \%$ and (e) $32 \mathrm{wt} \%$.



Figure 2. X-ray diffraction patterns $(\mathrm{Cu} \mathrm{K} \alpha)$ of the pristine $\mathrm{CNT}$ and $\mathrm{TiO}_{2} /$ CNT nanocomposites with various $\mathrm{TiO}_{2}$ contents.

where $I$ is the number of photoelectron per second in a specific spectra peak, $F$ is the atomic sensitivity factor, $i$ is the $\mathrm{TiO}_{2}$ element. According to the XPS results, $\mathrm{TiO}_{2} / \mathrm{CNT}$ composites contained $\mathrm{TiO}_{2}$ particle of correctly $4 \mathrm{wt} \%, 6 \mathrm{wt} \%, 17 \mathrm{wt} \%$ and $32 \mathrm{wt} \%$ on CNT, respectively.

Fig. 4 shows the nitrogen adsorption isotherms of the (a) CNT and the CNT on which $\mathrm{TiO}_{2}$ was deposited with contents of (b) 4 , (c) 6 , (d) 17, and (e) $32 \mathrm{wt} \%$. An increase in the $\mathrm{TiO}_{2}$ con- 

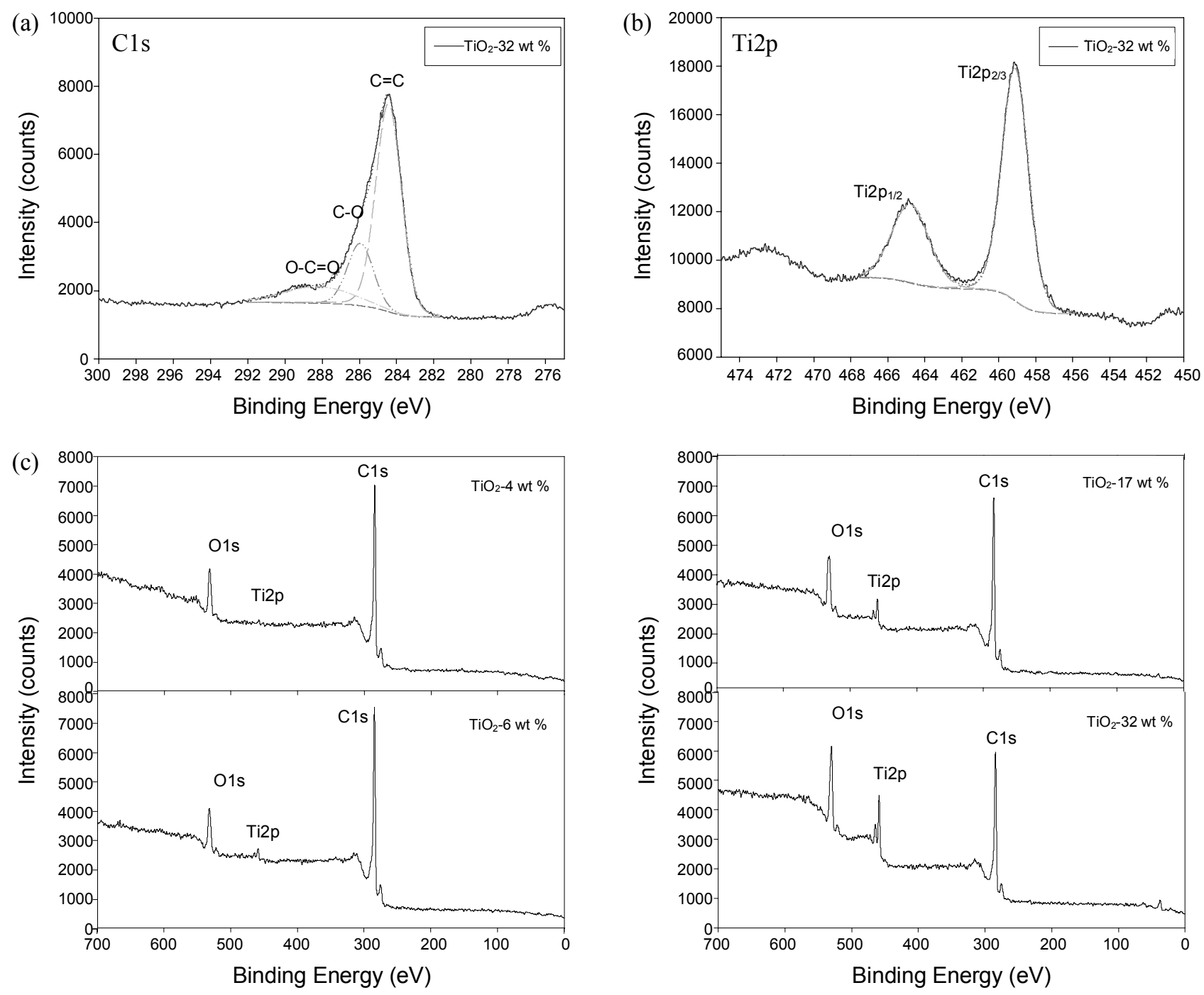

Figure 3. The X-ray photoelectron spectroscopic scans of the pristine $\mathrm{CNT}$ and $\mathrm{TiO}_{2} / \mathrm{CNT}$ nanocomposites with various $\mathrm{TiO}_{2}$ contents. (a) $\mathrm{C} 1 \mathrm{~s}$ (32 wt \%), (b) Ti2p (32 wt \%), and (c) wide scans of $\mathrm{TiO}_{2} / \mathrm{CNT}$ nanocomposites.

tents a great enhancement in the nitrogen adsorption capacity. Fig. 5 shows the BET surface area of the pristine $\mathrm{CNT}$ and $\mathrm{TiO}_{2} /$ CNT nanocomposites with various deposited $\mathrm{TiO}_{2}$ contents. After deposition of $\mathrm{TiO}_{2}$, surface area raises the porosity of the $\mathrm{TiO}_{2} / \mathrm{CNT}$ composite to improve BET specific surface area. When comparing those $\mathrm{TiO}_{2} / \mathrm{CNT}$ composites, $4 \mathrm{wt} \% \mathrm{TiO}_{2} /$ CNT composites and $6 \mathrm{wt} \% \mathrm{TiO}_{2} / \mathrm{CNT}$ composites have higher specific surface area. The pore distribution of $\mathrm{TiO}_{2} / \mathrm{CNT}$ nanocomposites is exhibited in Table 1 . As seen in this Table, the 4 wt $\%$ and 6 wt $\% \mathrm{TiO}_{2} / \mathrm{CNT}$ composites showed most excellent values of specific surface area $\left(341 \mathrm{~m}^{2} \mathrm{~g}^{-1}\right)$ and micro pore area $\left(17 \mathrm{~m}^{2} \mathrm{~g}^{-1}\right)$ compared with the pristine CNT, respectively. But higher contents of deposited $\mathrm{TiO}_{2}$ decreased both specific surface area and micro pore area.

The effect of $\mathrm{TiO}_{2}$ on the capacitance property of the $\mathrm{TiO}_{2} /$ CNT composite material was measured by cyclic voltammetry. Fig. 6 shows the cyclic voltammograms in $1 \mathrm{M} \mathrm{H}_{2} \mathrm{SO}_{4}$ electrolyte in the range of $0 \sim 800 \mathrm{mV}$ at $50 \mathrm{mVs}^{-1}$. In order to determine a good composition ratio of the $\mathrm{TiO}_{2} / \mathrm{CNT}$ electrode, the capacitances with different ratios of $\mathrm{TiO}_{2}$ contents were measured in
$1 \mathrm{M} \mathrm{H}_{2} \mathrm{SO}_{4}$. The specific capacitance $C_{\mathrm{s}}$ can be calculated from the cyclic voltammetry according to the equation (2):

$$
C_{\mathrm{s}}=\left[\left(i_{\mathrm{c}}+i_{\mathrm{a}}\right) / 2 / \mathrm{v}\right] / w
$$

where $i_{\mathrm{c}}$ and $i_{\mathrm{a}}$ are currents at $0.0 \mathrm{~V}$ during the cathodic and anodic sweeps, respectively, $v$ is the sweep rate, and $w$ is the total weight of the active material in one electrode. The anomalous increase in the current was caused by an enhancement of the electronic and/or ionic transfer between $\mathrm{TiO}_{2} / \mathrm{CNT}$ nanocomposite electrode and electrolyte. When $\mathrm{TiO}_{2}$ content was small, its double layer capacitance was only slightly higher than that of pristine CNT. But with increasing the $\mathrm{TiO}_{2}$ content ratio, the capacitance was decreased on account of improvement in diffusion resistance from impedance analysis of Fig. 7. From the result, we suggest the optimized content of $\mathrm{TiO}_{2}$ to be $4 \mathrm{wt} \%$ in $\mathrm{H}_{2} \mathrm{SO}_{4}$ electrolyte. The specific capacitance of the pristine CNT and $\mathrm{TiO}_{2} / \mathrm{CNT}$ composite electrodes are listed in Table 1 . The $4 \mathrm{wt} \% \mathrm{TiO}_{2} / \mathrm{CNT}$ composite electrode delivered a specific capacitance of $37 \mathrm{Fg}^{-1}$ which is higher than CNT electrode by $15 \mathrm{Fg}^{-1}$. 

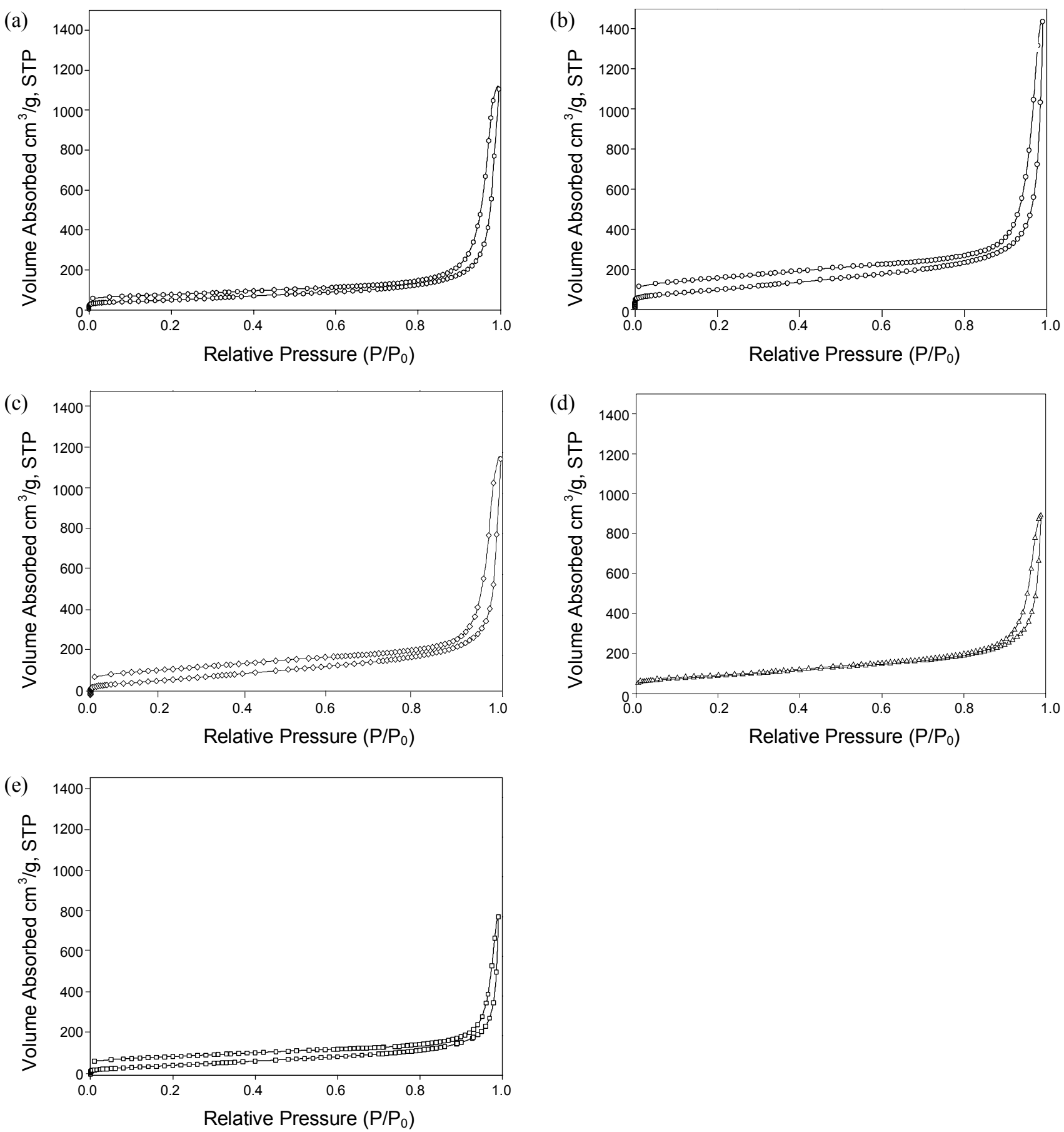

Figure 4. Nitrogen adsorption/desorption isotherms of the (a) the pristine $\mathrm{CNT}$ and $\mathrm{TiO}_{2} / \mathrm{CNT}$ nanocomposites with deposited $\mathrm{TiO}_{2}$ contents of (b) $4 \mathrm{wt} \%$, (c) $6 \mathrm{wt} \%$, (d) $17 \mathrm{wt} \%$ and (e) $32 \mathrm{wt} \%$.

It has been reported ${ }^{20}$ that the capacitance of an electrochemical capacitor is proportional to ion concentration and inversely proportional to the thickness of the double-layer, and the ion concentration is affected by the voltage between CNT electrodes and electrolyte. Based on above results, the increase of the capacitance in Table 1 could be attributed to the reduced polarization of CNT electrodes, which is believed to relate to the concentration of electric charges on $\mathrm{TiO}_{2}$ surface with increasing wettability. And electric field adsorption of electrolyte on the CNT composite electrode was significantly enhanced by $\mathrm{TiO}_{2}$ introduction due to the increase in the charge density of ions under electric field. ${ }^{21}$

A more detailed estimation of the electrochemical properties of the pristine $\mathrm{CNT}$ and $\mathrm{TiO}_{2} / \mathrm{CNT}$ composite electrodes can be carried out by analysis of the impedance spectra. Fig. 7 shows Nyquist plots of the pristine $\mathrm{CNT}$ and $\mathrm{TiO}_{2} / \mathrm{CNT}$ composite electrodes in $1 \mathrm{M} \mathrm{H}_{2} \mathrm{SO}_{4}$. The plot is composed of a semicircle at high frequency and a nearly vertical line at low frequency. The 


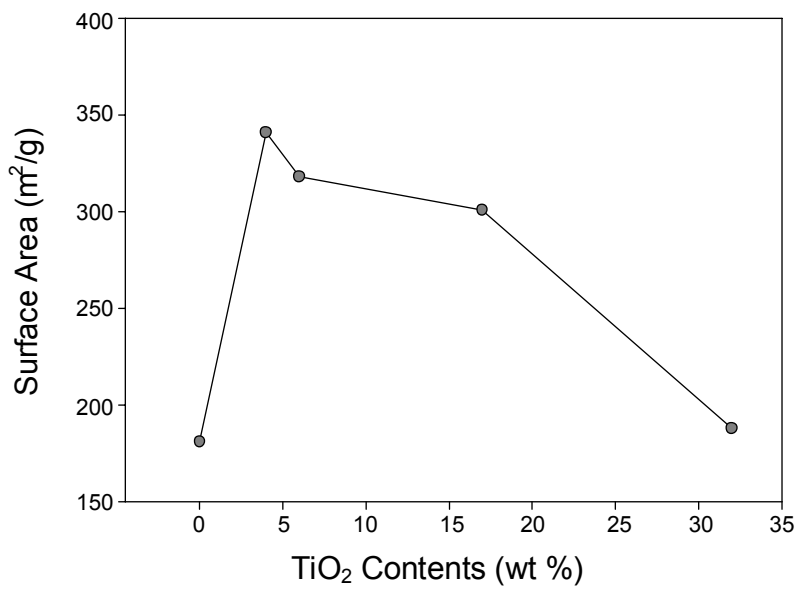

Figure 5. BET Surface area of the pristine $\mathrm{CNT}$ and $\mathrm{TiO}_{2} / \mathrm{CNT}$ nanocomposites with various deposited $\mathrm{TiO}_{2}$ contents.



Figure 6. Cyclic voltammograms of the pristine $\mathrm{CNT}$ and $\mathrm{TiO}_{2} / \mathrm{CNT}$ composite electrodes at scan rate of $50 \mathrm{mVs}^{-1}$ in $1 \mathrm{M} \mathrm{H}_{2} \mathrm{SO}_{4}$ electrolyte.

Table 1. BET surface area, specific capacitance and discharge capacitance of the $\mathrm{CNT}$ and $\mathrm{TiO}_{2} / \mathrm{CNT}$ nanocomposites

\begin{tabular}{ccccc}
\hline Content $\left(\mathrm{TiO}_{2}\right.$ wt \%) & BET $\left(\mathrm{m}^{2} \mathrm{~g}^{-1}\right)$ & Micro pore area $\left(\mathrm{m}^{2} \mathrm{~g}^{-1}\right)$ & Specific capacitance $\left(\mathrm{Fg}^{-1}\right)$ & Discharge capacitance $\left(\mathrm{Fg}^{-1}\right)$ \\
\hline $\mathbf{0}$ & 181 & 10 & 22 & 8 \\
$\mathbf{4}$ & 341 & 13 & 37 & 11 \\
$\mathbf{6}$ & 318 & 17 & 30 & 9 \\
$\mathbf{1 7}$ & 301 & 13 & 22 & 8 \\
$\mathbf{3 2}$ & 188 & 2 & 23 & 5 \\
\hline
\end{tabular}



Figure 7. Nyquist plots of the pristine $\mathrm{CNT}$ and $\mathrm{TiO}_{2} / \mathrm{CNT}$ nanocomposites with various deposited $\mathrm{TiO}_{2}$ contents.

high frequency intercepts the real-axis bulk resistance of composite electrodes. The semicircle consists of electrode resistance of the pristine $\mathrm{CNT}$ and $\mathrm{TiO}_{2} / \mathrm{CNT}$ composite electrodes. The bulk resistance of the capacitor built from CNT electrode was $1.7 \sim 1.8 \Omega$ at $5.6 \mathrm{kHz}$. The resistances of the CNT electrodes with $\mathrm{TiO}_{2}$ ratio of $4 \mathrm{wt} \%, 6 \mathrm{wt} \%, 17 \mathrm{wt} \% 32 \mathrm{wt} \%$ showed 3.8 , $2.3,2.4$ and $2.4 \Omega$ at $7.9,12.5,7.9$ and $5 \mathrm{kHz}$, respectively. The resistances of the electrode/electrolyte interface on $\mathrm{TiO}_{2} / \mathrm{CNT}$ composite electrodes were slightly higher than CNT electrode. The considerable effect of the Warburg impedance on the $4 \mathrm{wt}$ $\% \mathrm{TiO}_{2} / \mathrm{CNT}$ composite electrode shows a good capacitor-like behavior of near vertical slope to $10 \mathrm{mHz}$. The Warburg imped-

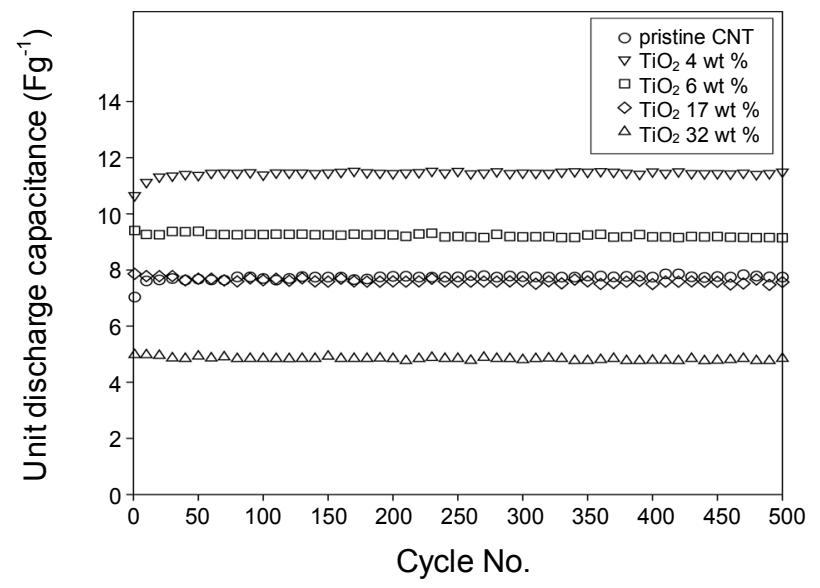

Figure 8. Cycle life performance of the pristine $\mathrm{CNT}$ and $\mathrm{TiO}_{2} / \mathrm{CNT}$ electrodes at $0.5 \mathrm{mAcm}^{-2}$ in $1 \mathrm{M} \mathrm{H}_{2} \mathrm{SO}_{4}$ electrolyte.

ance represents that the more the sloping line nears to the imaginary-axis, the more bulk resistance decreases. A Warburg diffusion element is incorporated in the circuit to emphasize the distributed resistance for ion diffusion in the micropores. ${ }^{22}$ The results indicate that the composite material reduced the polarization and improved the hydrophilicity of the CNT surface, resulting in the decrease of internal resistance between electrode and electrolyte and increase of the efficiency of charge and masstransfer on the electrode/electrolyte interface. ${ }^{5}$

This result of Nyquist plot agreed well with that from the cycle life performance. Fig. 8 shows the variation in unite discharge capacity as a function of cycle number (voltage range 


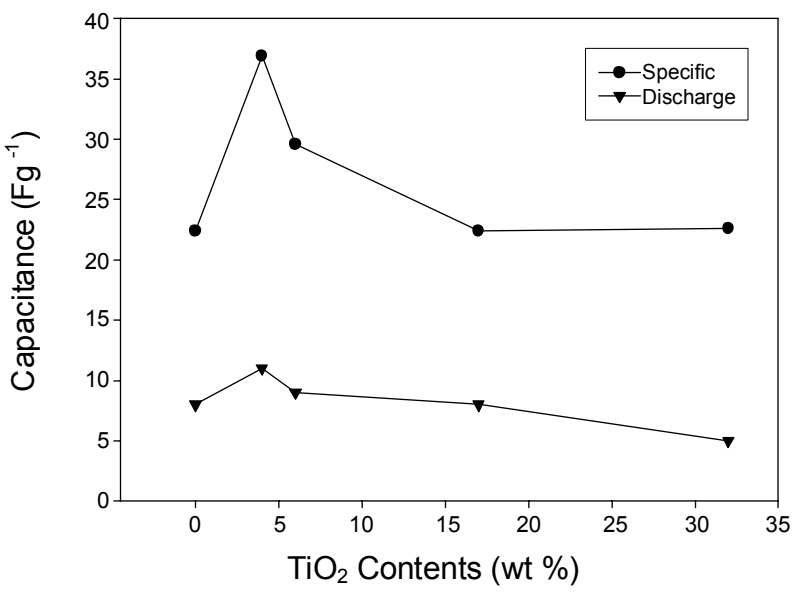

Figure 9. The effect of the contents of $\mathrm{TiO}_{2}$ nanoparticle on the capacitance.

between 0 and $1 \mathrm{~V}$, at $0.5 \mathrm{mAcm}^{-2}$ ). The discharge capacitance $\left(C_{\mathrm{d}}\right)$ was calculated from the equation $(3)$ :

$$
C_{\mathrm{d}}\left(\mathrm{Fg}^{-1}\right)=i \Delta t / m \Delta V
$$

where $i$ is the current density, $\Delta t$ is the discharge time, $m$ is the mass of the composite material, and $\Delta V$ is the potential range of the charge-discharge cycle. Regardless of the $\mathrm{TiO}_{2}$ contents, symmetric cells showed the similar variation trend in unit discharge capacity with cycle : all capacitances showed a small loss in the first 10 cycles, and then remained almost constant as cycling continued. The average values of unit discharge capacity for the $\mathrm{TiO}_{2} / \mathrm{CNT}$ composite electrodes and CNT electrode are listed in Table 1 . The electrodes with $4 \mathrm{wt} \%$ and $6 \mathrm{wt} \%$ deposited $\mathrm{TiO}_{2}$ not only delivered a unite discharge capacity of 11 $\mathrm{Fg}^{-1}$ and $9 \mathrm{Fg}^{-1}$, respectively, but also maintained an excellent cycling stability.

The dependence of specific capacitance on $\mathrm{TiO}_{2}$ contents is shown in Fig. 9. The CNT composite electrode with $4 \mathrm{wt} \%$ of deposited $\mathrm{TiO}_{2}$ shows higher capacitance and surface area than pristine CNT. From the result, it is indicated that increasing surface area and reducing polarization increase specific capacitance of CNT with $\mathrm{TiO}_{2}$ nanoparticle. Table 1 summarizes the values of all the surface area and capacitance for the $\mathrm{TiO}_{2} / \mathrm{CNT}$ composite electrodes along with the pristine CNT.

\section{Conclusion}

In the present work, CNT-based $\mathrm{TiO}_{2}$ nanocomposites were successfully prepared by a simple method using ultrasound, and $\mathrm{TiO}_{2}$ nanoparticles $(<20 \mathrm{~nm})$ were partly deposited onto CNT. Nanocomposites electrodes with $4 \sim 6 \mathrm{wt} \%$ of deposited $\mathrm{TiO}_{2}$ presented a better BET surface area compared with the pristine CNT. From Potentiostat/Galvanostat measurements in $1 \mathrm{M} \mathrm{H}_{2} \mathrm{SO}_{4}$ aqueous solution, the specific capacitance and electrochemical performance improved through titanium oxide composition introduction. The specific capacitance of the com- posite electrode increased from $22 \mathrm{Fg}^{-1}$ to $37 \mathrm{Fg}^{-1}$ in comparison with the pristine CNT from cyclic voltammogram. And cycle life performance of the symmetric cell showed increase in capacitance from $8 \mathrm{Fg}^{-1}$ to $11 \mathrm{Fg}^{-1}$ and maintained an excellent cycling stability. We suggest the optimized content of $\mathrm{TiO}_{2}$ to be 4 wt $\%$ and the increase in specific capacitance can be attributed to the decrease in electric polarization, caused by the deposition of $\mathrm{TiO}_{2}$ nanoparticles on the CNT. This conclusion is supported by the Warburg impedance behavior showed near vertical slope to $10 \mathrm{mHz}$.

Acknowledgments. This work was financially supported by KOSEF through the Research Center for Energy Conversion and Storage and the Korea Institute of Energy and Resources Technology Evaluation and Planning.

\section{References}

1. Conway, B. E. Electrochemical Supercapacitor-Scientific Fundamentals and Technological Application; Kluwer Academic: New York, 1999; p 29-31.

2. Koetz, R.; Carlen M. Electrochimica Acta 2000, 45, 2483.

3. Frackowiak, E.; Béguin, F. Carbon 2001, 39, 937.

4. Fuertes, A. B.; Lota, G.; Centeno, T. A.; Frackowiak, E. Electrochimica Acta 2005, 50, 2799.

5. Liang, H.; Chen, F.; Li, R.; Wang, L.; Deng, Z. Electrochimica Acta 2004, 49, 3463.

6. Morita, M.; Goto, M.; Matsuda, Y.J. Appl. Electrochem. 1992, 22, 901.

7. Tanahashi, T.; Yoshida, A.; Nishino, A. J. Electrochem. Soc. 1990, 137,3052

8. Rudge, A.; Raistrick, I.; Gottesfeld, S.; Ferraris, J. P. Electrochimica Acta 1994, 39, 273.

9. Rudge, A.; Davey, J.; Raistrick, I.; Gottesfeld, S.; Ferraris, J. P. J. Power Sources 1994, 47, 89.

10. Hu, C. C.; Su, J. H.; Wen, T. C. J. of Physics and Chemistry of Solids 2007, 68, 2353.

11. Zhou, Y. K.; He, B. L.; Zhou, W. J.; Huang, J.; Li, X. H.; Wu, B.; Li, H. L. Electrochimica Acta 2004, 49, 257.

12. Ye, J. S.; Liu, X.; Cui, H. F.; Zhang, W. D.; Sheu, F. S.; Lim, T. M. Electrochemistry Communications 2005, 7, 249.

13. Show, Y.; Imaizumi, K. Diamond \& Related Materials 2007, 16, 1154.

14. Kim, J. H.; Nam, K. W.; Ma, S. B.; Kim, K. B. Carbon 2006, 44, 1963.

15. Frackowiak, E.; Metenier, K.; Bertagna, V.; Béguin, F. Appl. Phys. Lett. 2000, 77, 2421.

16. Frackowiak, E.; Jurewicz, K.; Delpeux, S.; Béguin, F. J. Power Sources 2001, 97/98, 822.

17. Rong, C.; Xien, H. J. of Colloid and Interface Science 2005, 290 , 190.

18. Tashima, D.; Kurosawatsu, K.; Uota, M.; Karashima, T.; Otsubo, M.; Honda, C.; Sung, Y. M. Thin Solid Films 2007, 515, 4234.

19. Xia, X. H.; Jia, Z. J.; Yu, Y.; Liang, Y.; Wang, Z.; Ma, L. L. Carbon 2007, 45, 717.

20. Qu, D.; Shi, H. J. Power Sources 1998, 74, 99.

21. Ryoo, M. W.; Kim, J. H.; Seo, G. J. of Colloid and Interface Science 2003, 264, 414.

22. Huang, C. W.; Chuang, C. M.; Ting, J. M.; Teng, H. J. of Power Sources 2008, 183, 406. 